Iryna Norkina, student

Taras Shevchenko National University of Kyiv, Kyiv, Ukraine

\title{
CRISIS INTERVENTION IN THE CASE OF PSYCHOTRAUMATIC SITUATION
}

The article deals with the questions of the psychologist's activity regarding assistance to the person in crisis. The basics of the theory of crisis intervention are outlined, the concept of crisis is operationalized and criteria for distinguishing between the concepts of micro trauma and micro trauma are introduced. The conceptual apparatus of the approach is developed in detail and the necessity of its unified understanding by practical psychologists is substantiated. The purpose of the article is to analyze the process of crisis intervention in the activity of the psychological service (psychologist), which takes measures to resolve the traumatic situation and reduce its impact on human life. An important factor in crisis intervention is the psychologist's understanding of the nature of the crisis, the severity and mechanisms of its experience. An important place is given to the stages of personal response, which determines the strategy and directions of professional intervention. Analyzing the process of crisis intervention in the activities of a psychologist (psychological service) identified important tasks that should be implemented: 1) the removal of symptoms; 2) recovery to crisis level of functioning; 3) awareness of those events that lead to an imbalance; 4) identify the internal resources of the client and family in various forms of crisis management assistance. The theoretical and practical recommendations given are outlined by the use of the voyage method, based on the real case of a crisis situation, which led to psychological trauma in participants and witnesses. As the above case is related to a terrorist act, the article also provides theoretical and methodological information regarding the specificity of the work of a psychologist with the concept of terrorism and the peculiarities of its impact on participants and witnesses of such acts. Based on the results of the case study, the author formulated practical recommendations for practicing psychologists on what to consider when dealing with an injury, especially if it was caused by an act of terrorism. The article concludes with the need to take into account the emotional reactions of a person to a crisis and the long-term changes in their ability to withstand daily problems. Crucial in dealing with clients is given to the psychological conditions that are discussed in detail in the article.

Keywords: traumatic situation, micro and macro traumas, crisis, crisis counseling.

Ирина Норкина, студ

Киевский национальный университет имени Тараса Шевченко, Киев, Украина

\section{КРИЗИСНОЕ ВМЕШАТЕЛЬСТВО В СЛУЧАЕ ПСИХОТРАВИРУЮЩЕЙ СИТУАЦИИ}

В статье рассматриваются вопросы деятельности психолога о помощи личности в кризисной ситуации. Важным фактором кризисного вмешательства есть понимание психологом сущности кризисной ситуации, степени тяжести и механизмы ее переживания. Важное место отведено учету стадий реагирования личности, определяет стратегию и направления профессионального вмешательства. Анализируя процесс кризисного вмешательства в деятельности психолога (психологической службы) выявлень важные задачи, которые должны быть реализованы: 1) снятие симптомов 2) восстановление до кризисного уровня функционирования; 3) осознание тех событий, которые приводят к состоянию дисбаланса; 4) выявление внутренних ресурсов клиента и членов семьи в различных формах помощи для преодоления кризиса.

Ключевые слова: психотравмирующая ситуация, микро- и макротравмы, кризис, кризисное консультирование.

Bulletin of Taras Shevchenko National University of Kyiv.

Series "Psychology". № 1(10), pp. 78-81 (2019)

УДК 159.922.4

DOI: https://doi.org/10.17721/BSP.2019.1(10).20
ISSN 1728-3817

(C) Taras Shevchenko National University of Kyiv,

Publishing Center "Kyiv University", 2019

Віталій Онищенко, студ. Київський національний університет імені Тараса Шевченка, Київ, Україна

\section{РОЗВИТОК ЦІЛЬОВОЇ СПРЯМОВАНОСТІ ОСОБИСТОСТІ ПІДЛІТКІВ-ТУРИСТІВ}

Наведено результати вивчення розвитку цільової спрямованості особистості підлітків-туристів. Дослідження полягає у припущенні про те, що прискорення розвитку цільової спрямованості особистості у підлітків можливо иляхом активізації їі складових в умовах туристичної діяльності. Взаємодія у групі під час змагань та подорожей сприяє розвитку колективізму й комфортного мікроклімату, що впливає на емоційну сферу підлітків. Застосування карток орієнтовної основи дії на тренуваннях викликає пізнавальну активність, зростання мотивації до навчання, а також розвиток раціональної та альтруїстичної позицій цільової спрямованості особистості підлітків. Ситуації випробування під час тренувань та змагань, складні ділянки маршруту й несприятливі погодні умови в поході спричиняють корекцію конативного компоненту. Система змінних посад, туристичні правила та цінності сприяють розвитку ціннісного компоненту цільової спрямованості підлітків.

Ключові слова: психологічні особливості розвитку, цільова спрямованість особистості, особистість підлітка, туристична діяльність, професійний спорт.

Постановка проблеми. Актуальність дослідження визначається соціальною значущістю проблеми розвитку цільової спрямованості особистості підлітка, оскільки від її вирішення залежить якість життя зростаючої людини, її внутрішні зміни та саморозвиток. Цільова спрямованість відображається в особливостях взаємодії підлітків із навколишнім світом. Актуальність дослідження полягає також і у тому, що теоретичне визначення цільової спрямованості може стати у нагоді при розробці загальної теорії особистості, яка являє собою багатовимірну систему. Одним із таких вимірів $є$ діяльнісний, який містить потребнісно-мотиваційні, інформаційно-пізнавальні, цілеутворювальні компоненти.

Аналіз останніх досліджень і публікацій. Стосовно окресленої проблематики можна виокремити такі напрями досліджень, які стосуються особистості в цілому (В. В. Рибалка, О. П. Саннікова, Е. Фромм, К.-Г. Юнг), спрямованості особистості (О.М.Леонтьєв, К. К. Платонов, С.Л. Рубінштейн), взаємозв'язку цілей і мотивації діяльності (Б. Ф. Ломов, Є. М. Нікіреєв, В.А.Семиченко), процесів цілеутворення (О.Ф. Коган, О. К. Тихомиров) та перспективи майбутнього часу (К. О. АбульхановаСлавська, К. К. Платонов). Цільова спрямованість розглядається системно у контексті мотиваційної сфери особистості (В. С. Вуколов, О. П. Гащук, С.Д. Максименко), виконанні творчих завдань (В. Є. Клочко, В.О.Моляко), самоактуалізації духовності (Г. О.Балл, В. О. Моляко, Т. М. Титаренко), вольової організації (В. А. Іванніков, С. Д. Максименко), саморегуляції (О. Я. Чебикін), пізнавальної діяльності (П. Я. Гальперін, Н. Ф. Тализіна). Психологічні аспекти структури цільової спрямованості особистості розглядаються у працях Я. В. Васильєва.

Проблема цільової спрямованості особистості підлітків досліджувалась у контексті розвитку особистості (К. О. Абульханова-Славська, Б. Г. Ананьєв, І.Д.Бех, Л. І. Божович, М. Й. Боришевський, І І. С. Булах, В. О. Татенко, Д.Й. Фельдштейн). Існує певна низка робіт, присвячених питанням розвитку особистості підлітків шляхом використання творчого потенціалу (К. О. АбульхановаСлавська, В.О. Моляко), тренінгових занять (І.С. Булах), спортивного туризму (П. І. Істомін, О. Н. Камакін, Л. Ф. Нікішина). Водночас специфріка використання туристичної діяльності як засобу розвитку цільової спрямованості особистості підлітків не була предметом спеціальних досліджень. Для повноти зображення проблеми слід додати позашкільну діяльність у формі проведення туристичних занять (О. П. Гащук, М. Ю. Костриця), які дозволяють фрормувати вольові якості (Ю. М. Кизиченко, Н. О. Тимофееєва), активізувати пізнавальну діяльність, командний дух (Л. О. Вяткін, О. П. Гащук, Е. Е. Лінчевський), сприяють саморозвитку і самопізнанню тощо (І. В. Зорін, Є. П. Ільїн, А. Т. Перкова). 
Мета статті - теоретично обґрунтувати та емпірично вивчити цільову спрямованість особистості підлітків, особливості її розвитку в процесі туристичної діяльності.

Виклад основного матеріалу. Складність процесу вивчення цільової спрямованості особистості підлітка, вікові та індивідуальні особливості учнів зумовили необхідність використання взаємодоповнювальних методик. Відповідно до теми, мети та напрямів експериментального дослідження було підібрано взаємодоповнювальні методики: методика дослідження цільової спрямованості особистості Я. В. Васильєва; тест-опитувальник Кеттела для підлітків; методика "Прислів'я" С.М.Петрової; методика "Мета - засіб результат" А.А.Карманова; методика дослідження вольової організації особистості М. С. Гуткіна; методика вивчення мотивації навчання підлітків М.І.Лук'янової.

Дотримання зазначеного підходу та врахування вікових характеристик підлітків дає можливість за відповідними методиками виявити особливості цільової спрямованості досліджуваної категорії людей. Емпіричне дослідження цільової спрямованості особистості підлітка передбачає діагностику за описаними вище компонентами - емоційним когнітивним, конативним та ціннісним.

У дослідженні брали участь 60 учнів сьомих класів Київської ЗОШ № 48, 20 учнів Київської гімназії № 2,
20 учнів восьмих класів Київського обласного центру туризму краєзнавства та екскурсій учнівської молоді. Загальну вибірку становили 60 школярів - 30 жіночої та 30 чоловічої статі. Для забезпечення повноти вивчення компонентів цільової спрямованості особистості у підлітковому віці кількісний та якісний аналіз отриманих даних супроводжувався фрагментами феноменологічних методик (висловлюваннями із бесід з учнями, записами у щоденниках).

Для проведення другого етапу експерименту за основу було взято методику дослідження цільової спрямованості особистості Я. В. Васильєва. Вона дозволяє виявити сфери цільової спрямованості, визначити рівневу структуру сорер цільової спрямованості особистості підлітків, а також позиції, які займають підлітки згідно з поставленими цілями. Інші методики констатуючого експерименту виконували допоміжну роль для уточнення взаємин по лінії "цілі - особистість".

Всього було проаналізовано 70 цілей, які становили сім сфрер спрямованості особистості (табл. 1). Перед підлітками ставили завдання не тільки розташувати цілі за значущістю, але й оцінити час здійснення, реалізацію, залежність від себе, емоційне ставлення та вольове зусилля за десятибальною шкалою.

Кількісні характеристики сфер цільової спрямованості підлітків

\begin{tabular}{|l|c|c|c|c|c|c|c|c|c|}
\hline $\begin{array}{c}\text { Сфери } \\
\text { спрямованості }\end{array}$ & $\begin{array}{c}\text { Загальна } \\
\text { кількість } \\
\text { цілей }\end{array}$ & $\begin{array}{c}\text { \% до } \\
\text { загального } \\
\text { обсягу цілей }\end{array}$ & $\begin{array}{c}\text { Вихідний } \\
\text { список } \\
\text { цілей }\end{array}$ & $\begin{array}{c}\text { 3начущість } \\
\text { цілей }\end{array}$ & $\begin{array}{c}\text { Час } \\
\text { здійснення } \\
\text { цілей }\end{array}$ & $\begin{array}{c}\text { Pеалізація } \\
\text { цілей }\end{array}$ & $\begin{array}{c}\text { 3алежність } \\
\text { від мене }\end{array}$ & $\begin{array}{c}\text { Емоційне } \\
\text { ставлення }\end{array}$ & $\begin{array}{c}\text { Вольове } \\
\text { зусилля }\end{array}$ \\
\hline Особистісна & 16 & 23 & 6,1 & 7,3 & 4,8 & 6,1 & 6,6 & 7,1 & 6,2 \\
\hline Інтимна & 4 & 6 & 8,2 & 10,1 & 5,7 & 5,1 & 5,3 & 5,2 & 5,0 \\
\hline Сімейна & 9 & 13 & 9,9 & 9,2 & 5,2 & 4,3 & 4,6 & 6,9 & 5,4 \\
\hline Дружня & 12 & 17 & 7,6 & 8,4 & 3,6 & 5,7 & 5,4 & 7,3 & 5,2 \\
\hline Навчальна & 8 & 12 & 11,2 & 10,6 & 4,2 & 5,2 & 5,2 & 5,4 & 5,9 \\
\hline Суспільна & 6 & 10 & 12,5 & 11,3 & 6,1 & 4,0 & 4,8 & 4,2 & 3,8 \\
\hline Самодіяльна & 13 & 19 & 9,7 & 9,8 & 3,5 & 6,9 & 6,8 & 5,3 & 5,3 \\
\hline
\end{tabular}

Результати проведеної методики показують перевагу кількості цілей, пов'язаних із особистими потребами. Особиста сфрера цільової спрямованості містить цілі, пов'язані з піклуванням про себе, орієнтовані на своє "Я". Вони у своїй більшості егоцентричні, меркантильні й утилітарні. Але до цієї самої сфери належить і цілі, спрямовані на підтримку здоров'я та на самовдосконалення. Особистісна ссрера становить $23 \%$ від загального обсягу цілей, що свідчить про зосередження сучасних підлітків на сьогоденні, вони стають егоцентричними.

На другому місці за кількістю цілей - самодіяльна copepa (19\%). Це свідчить про важливість для даного вікового періоду проведення дозвілля, наявності власного хобі. Пошук власного Я та реалізація себе у групі $\epsilon$ характерним для підліткового віку.

Третє місце посідає дружня сфрера - $17 \%$. У ній зосереджені цілі, пов'язані зі спілкуванням у групі, друзями та іншими людьми. У підлітковому віці дитина більше часу проводить із друзями, наслідує їх, тому її цілі стають усе більше пов'язані саме із дружньою сферою.

Сімейна (13\%) та навчальна (12\%) сфери не мають високих показників. Цілі сімейної ссери належить до батьківської сім'ї, тобто ставлення до батьків, бабусь і дідусів, братів і сестер, рідного дому. Такі дані пояснюються тим, що у підлітковому віці відбувається розрив із батьками, непорозуміння із вчителями через відмову дорослих сприймати підлітків як самостійну особистість. Прагнення потрапити до світу дорослих та реалізуватися там, як повноцінного члена суспільства, натикається на обурення й непорозуміння, що і спричиняє падіння авторитетів батьків та вчителів, адаптацію підлітків до соціуму через звернення за підтримкою до однолітків і зменшення кількості цілей у цих сферах. Проведений зріз показав, що підлітки воліють скоріше до самоосвіти, спостерігається байдужість до шкільних оцінок. Це пояс- нює розбіжність між інтелектуальними можливостями та успіхами у школі: можливості високі, а успіхи низькі.

Найменші показники мають інтимна $(6 \%)$ та суспільна (10\%) сорери. Такі результати вказують на те, що фантазія підлітка обернена в інтимну сферу, але вона приховується від людей. Тому кількість написаних цілей не збігається 3 реальним станом. Цілі інтимної сфери спрямовані на відносини із протилежною статтю. Вони стосуються питань кохання, у тому числі і статевого, створення власної сім'ї, одруження й заміжжя, відтворення покоління. Хвилювання, пов'язанні з висміюванням та нерозумінням власних бажань щодо цієї сфери іншою людиною (особливо дорослим), перевищують потяг до їх озвучення.

Зміст суспільної сфери стосується загальнолюдських цінностей, політичних та ідеологічних поглядів, а практична діяльність не пов'язана із професійною чи навчальною діяльністю, або пов'язана опосередковано. Падіння культури та морального розвитку в суспільстві зумовлюють той фракт, що віддаленим та більш значущим цілям, спрямованим на суспільство, підлітки приділяють найменше уваги. Добробут i благополуччя держави, вищі вияви благородства та честі для них здебільшого неважливі. Це робить актуальним проведення нашого дослідження в контексті розвитку цільової спрямованості підлітків.

Можливість реалізації цілей підлітками визначалась за десятибальною оцінкою. Чим вище вірогідність досягнення поставленої мети, тим вищий бал. Згідно з цим показником найбільша ймовірність досягнення цілей у самодіяльної сфери становить 6,9 балів. Наступне місце займає особистісна сфера. Ïї оцінка - 6,1 бали. 3овсім поряд знаходиться дружня сфера - 5,7 балів. Ці дані мають близький зв'язок із даними часу здійснення. Адже ті сфери, які вимагали найменшого часу для здій- 
снення, показали найбільші показники вірогідності реалізації. За дружньою сферою йде навчальна (5,2 бали) та інтимна (5,1 бали). Сімейна (4,3 бали) та суспільна (4,0 бали) займають останні позиції. Тут, знову ж таки, простежується зв'язок із часом здійснення цілей. Цілі, які вимагають найбільше часу для реалізації, мають найменшу вірогідність для здійснення.

Наступна колонка - залежності цілей від самої особистості. Отримані дані показали, що підлітки дуже низько оцінюють власні сили у досягненні поставленої мети. Вони більше сподіваються на вплив сторонніх факторів, аніж на самих себе. Така ситуація свідчить про високий рівень невпевненості у власних силах. Найвищий показник із 10-ти балів має самодіяльна сфрера - 6,8 балів. Наступною йде особистісна сфера 6,6 балів. Отож можна побачити, що більш високі сподівання на власні сили, для реалізації поставленої мети, присутні лише у сфрерах, пов'язаних із власним "Я". Інші ссрери мають значно нижчі оцінки: дружня - 5,4 бали, інтимна - 5,3 бали, навчальна - 5,2 бали, суспільна 4,8 бали, сімейна - 4,6 бали. Останню позицію сімейної сорери забезпечує саме несприйняття старшими самостійності дитини та тиск з боку батьків.

Дані, отримані стосовно емоційного ставлення та вольових зусиль підлітків щодо реалізації цілей та докладання зусиль для запобігання невдач, указують на неоднозначне ставлення до проблеми. 3 одного боку, підлітки вказують, що нездійснення цілей певної сфери призведуть до емоційної напруженості, а з іншого - вони не докладатимуть значних зусиль, щоб дані цілі реалізувати. Це пов'язано з тим, що, на нашу думку, у багатьох підлітків спостерігається неадекватна реакція на невдачу. Мета може бути доволі реалістична і продумана, всі основні ланки майбутньої роботи визначені, і все-таки це не рятує від невдач, до яких підліток не готовий. Невдачу, навіть незначну, він сприймає як свідчення того, що він зовсім неспроможний досягнути мети. Далі виникає негативне емоційне забарвлення і розпочата справа не доводиться до кінця, що призводить до зниження оцінки власних вольових зусиль. Такий характер має дружня, особистісна та сімейна сфрери.

Значущість сфер, відповідно до бальної оцінки емоційного ставлення, така: дружня сфера - 7,3 бали, особистісна - 7,1 бали, сімейна - 6,9 балів, навчальна 5,4 бали, самодіяльна - 5,3 балів, інтимна - 5,2 бали, суспільна - 4,2 бали. Оцінка вольових зусиль, які докладатимуть підлітки для реалізації поставлених завдань, розташувала сфери таким чином: особистісна 6,2 бали, навчальна - 5,9 балів, сімейна - 5,4 балів, самодіяльна - 5,3 бали, дружня - 5,2 бали, інтимна 5,0 балів, суспільна - 3,8 балів. Як бачимо, суспільна сфрера знову залишається на останній позиції, що свідчить про неважливість її значення для підлітків.

Нами було узагальнено оцінювання цілей підлітками за всіма сфрерами спрямованості у вигляді рис. 1.

Наступним кроком було виявлення рівнів (позиції) цільової спрямованості підлітків. У концепції цільової спрямованості особистості Я.В.Васильєва виділено три позиції особистості, які характеризуються двома параметрами: предметним освоєнням світу і ставленням до інших людей. Перша позиція особистості спирається на ситуативні цілі, які спрямовані на задоволення біологічних і матеріальних потреб при егоцентричному ставленні до інших. Ця позиція цільової спрямованості особистості названа дослідником егоцентричною.

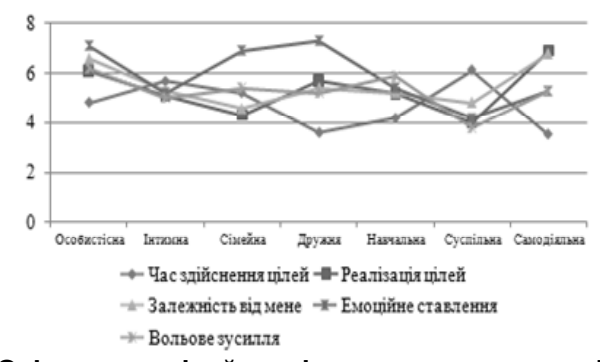

Рис. 1. Оцінювання цілей за сферами спрямованості підлітків

Близькі цілі спрямованості особистості, які займають раціональну позицію, забезпечують процес освоєння різних видів діяльності. Вони також пов'язані зі становленням престижної та прагматичної мотивації, заснованої на самоствердженні особистості.

Середні цілі спрямованості пов'язані із саморозвитком особистості, з повагою і турботою про інших. Такий рівень відповідає альтруїстичній позиції. Вона може бути розглянута як одна з базальних оперативних схем, що визначають ставлення людини до світу людей та її місце в цьому світі.

Для виявлення характерних особливостей цих рівнів у підлітковому віці ми провели статистичне порівняння за кількісними показниками так само, як це було зроблено при аналізі сфер цільової спрямованості особистості. За кожним із трьох рівнів наводяться кількісні показники загального складу цілей, їх відсоткове відношення, середнє арифметичне за вихідним списком і списком значущості цілей. Решта показників указує на середнє арифметичне, але обчислюється на основі десятибальної шкали.

Отримані дані показали, що за кількістю цілей переважає егоцентрична позиція, яка становить $49 \%$ від загальної вибірки. На другому місці - раціональна позиція (34\%), і останньою $є$ альтруїстична позиція $15 \%$. Такі дані свідчать про небажання підлітків ставити віддалені, більш благородні цілі, замість цього вони обирають близькі, орієнтовані на задоволення власних біологічних потреб. Результати зрізу стосовно позицій особистості підлітків наведено у табл. 2.

Таблиця 2

Кількісні характеристики рівнів (позицій) цільової спрямованості особистості підлітків

\begin{tabular}{|c|c|c|c|c|c|c|c|c|c|}
\hline $\begin{array}{c}\text { Позиції } \\
\text { особистості }\end{array}$ & $\begin{array}{c}\text { Загальна } \\
\text { кількість } \\
\text { цілей }\end{array}$ & $\begin{array}{c}\text { \% до } \\
\text { загального } \\
\text { обсягу }\end{array}$ & $\begin{array}{c}\text { Вихідний } \\
\text { список } \\
\text { цілей }\end{array}$ & $\begin{array}{c}\text { Значення } \\
\text { цілей }\end{array}$ & $\begin{array}{c}\text { Час } \\
\text { здійснення } \\
\text { цілей }\end{array}$ & $\begin{array}{c}\text { Реалізація } \\
\text { цілей }\end{array}$ & $\begin{array}{c}\text { Залежність } \\
\text { цілей } \\
\text { від мене }\end{array}$ & $\begin{array}{l}\text { Емоційне } \\
\text { ставлення }\end{array}$ & $\begin{array}{l}\text { Вольове } \\
\text { зусилля }\end{array}$ \\
\hline Альтруїстична & 11 & 15 & 12,35 & 11,75 & 8,4 & 3,4 & 3,9 & 3,7 & 4,2 \\
\hline Раціональна & 24 & 34 & 8,81 & 7,23 & 6,6 & 5,3 & 4,7 & 5,2 & 5,5 \\
\hline Егоцентрична & 36 & 49 & 5,29 & 7,87 & 3,1 & 6,7 & 5,2 & 6,1 & 6,3 \\
\hline
\end{tabular}

Дані табл. 2 змістовно наближені до характеристик сфрер спрямованості. Якщо у вихідному списку цілей на першому місці виступає егоцентрична позиція, на другому - раціональна, а на третьому - альтруїстична, то після раціональної обробки написаних цілей підлітки розташували їх таким чином, що за значенням на першому місці опинилася раціональна позиція, потім егоцентрична, потім альтруїстична.

Середній час віддаленості цілей у егоцентричної позиції - 3,1 бали, раціональної - 6,6 балів, альтруїстичної -
8,4 бали. Реалізація цілей трьох позицій така: егоцентрична - 6,7 балів, раціональна - 5,3 бали, альтруїстична 3,4 бали. Залежність реалізації цілей від себе підлітки оцінили таким чином: егоцентрична - 5,2 бали, раціональна - 4,7 бали, альтруїстична - 3,9 бали. Емоційне ставлення до поставлених цілей таке: егоцентрична 6,1 балів, раціональна - 5,2 бали, альтруїстична 3,7 бали. Вольові зусилля, які докладатимуть підлітки для реалізації поставлених цілей: егоцентрична - 6,3 балів, раціональна - 5,5 бали, альтруїстична - 4,2 бали. 
Висновки. Отримані дані констатувального експерименту підтверджують думку Д. Й. Фельдштейна, яку він висловив у своїй статті "Проблеми формування особистості зростаючої людини на новому історичному етапі розвитку суспільства". Він констатує наявність у підлітків зосередження на собі, пошуку власного сенсу життя, який іде всупереч дорослим членам суспільства. Звідси виникає напруга у відносинах між поколіннями, визначенням їх провідних цілей. Тому актуальним наразі буде не директивний підхід до їх бачення світу, а гуманістичний.

Д. Й. Фельдштейн стверджує, що емоційні та моральні цінності - чуйність, терпимість, уміння співпереживати посідають останні місця в ієрархії цінностей. Спостерігається негативна динаміка культурних і громадських ціннісних орієнтацій. У підлітків істотно зросло прагнення до самоствердження (домінування і самопрезентації). Але, водночас, різко змінилася особистісна спрямованість. Він наводить такі дані: у 1993 р. 58 \% дітей підліткового віку характеризувалися альтруїстичним настроєм, у 2013 р. такий тип спрямованості спостерігали тільки у $16 \%$. Отже, відбулося його зниження у три і шість десятих рази.

Таким чином, аналіз змістовної структури цільової спрямованості особистості дозволив побачити пріоритети ссрер спрямованості підлітків, а кількісні показники уможливили оцінити вплив різних чинників у цих сферах. Удалося зафіксувати кількість цілей у кожній зі сфер та їх місце у структурі цільової спрямованості підлітків. Було визначено кількісний показник значущості кожної із семи сфрер за несвідомої та свідомої постановки цілей, ступінь віддаленості цілей у кожній зі сфер особистості, отримано показники реалізації кожної мети на даний момент, і визначено, наскільки її кінцеве досягнення залежить від зусиль особистості. Такі самі показники були отримані й за кожною метою стосовно емоційного та вольового ставлення до неї. Також усі цілі було розділено на три групи відповідно до трьох позицій особистості: егоцентричної, раціональної та альтруїстичної.

Список використаних джерел

1. Борисов П. С. Технология спортивного туризма : метод. пособ. / П. С. Борисов, Ф. Д. Смык. - Кемерово : ГУ Куз-ГТУ, 2011. - 72 с.

2. Братусь Б. С. К проблеме нравственного сознания в культуре уходящего века / Б. С. Братусь // Вопросы психологии. - 1993. - № 1. - С. 26-35.

Vitalyi Onyschenko, student

Taras Shevchenko National University of Kyiv, Kyiv, Ukraine
3. Братусь Б. С. Психологические аспекты нравственного развития личности / Б. С. Братусь. - М. : Знание, 1977. - 64 с.

4. Булах I. С Психологія особистісного зростання підпітка / І. С. Булах [Електронний ресурс]. - К., 2003. - 340 с. - Код доступу: http://www.psyh.kiev.ua.

5. Бюлер Ш. Что такое пубертатный период / Ш. Бюлер // Психология подростка: хрестоматия / сост. Ю. И. Фролов. - М. : Рос. пед. агентство, 1997. - C. 9-19.

6. Adler, A. Social interest: A challenge to mankind. - New York: Capricorn Books, 1964. - 432 p.

7. Adler A. The individual psychology of Alfred Adler: A systematic presentation in selection from his writings (H. L. Ansbacher \& R. R. Ansbacher, Eds.). - New York: Harper \& Row, 1956. - 503 p.

8. Allport G. W. The person in Psychology. Boston: Beacon Press, 1968. $-440 \mathrm{p}$.

9. Fromm E. The Anatomy of Human Destructiveness. - New York: Holt, Rinehart and Winston, 1973. - 576 p.

10. Fromm E. The art of listening. - New York : Continuum, 1994. - 204 p.

11. Guilford J. P. Personality. - New York : McGrow-Hill, 1959. - 562 p.

12. Hull C. G. Principles of Behavior. An Introduction to behavior theory. New York, 1943. -422 p.

\section{References}

1. Borysov P. S. Tekhnolohyia sportyvnoho turyzma. Metodycheskoe posobye / P. S. Borysov, F. D. Smyk. - Kemerovo : HU Kuz-HTU, 2011. - 72 s.

2. Bratus B.S. K probleme nravstvennoho soznanyia $v$ kulture ukhodiashcheho veka/B. S. Bratus // Voprosy psykholohyy. - 1993. № $1 .-\mathrm{S}$. 26-35.

3. Bratus B. S. Psykholohycheskye aspekty nravstvennoho razvytyia lychnosty / B. S. Bratus. - M. : Znanye, 1977. - 64 s.

4. Bulakh I. S. Psykholohiia osobystisnoho zrostannia pidlitka/ I. S. Bulakh. - K. : NPU im. M. P. Drahomanova, 2003. $-340 \mathrm{~s}$.

5. Biuler Sh. Chto takoe pubertatnyi peryod/Sh. Biuler // Psykholohyia podrostka: khrestomatyia / sost. lu. Y. Frolov. - M. : Rossyiskoe pedahohycheskoe ahentstvo, 1997. - S. 9-19.

6. Adler A. Social interest: A challenge to mankind / A. Adler. - New York : Capricorn Books, 1964. - $432 \mathrm{p}$

7. Adler A. The individual psychology of Alfred Adler: A systematic presentation in selection from his writings / A. Adler // H. L. Ansbacher \& R. R. Ansbacher, Eds. - New York : Harper \& Row, 1956. - 503 p.

8. Allport G. W. The person in Psychology / G. W. Allport. - Boston : BeaconPress, 1968. - $440 \mathrm{p}$

9. Fromm E. The Anatomy of Human Destructiveness / E. Fromm. New York : Holt, Rinehart and Winston, 1973. - 576 p.

10. Fromm E. The art of listening / E. Fromm. - New York : Continuum, 1994. $-204 p$

11. Guilford J. P. Personality / J. P. Guilford. - New York: McGrow-Hill, 1959. $-562 p$.

12. Hull C. G. Principles of Behavior. An Introduction to behavior theory / C. G. Hull. - New York, 1943. -422 p.

Надійшла до редколегії 19.05.19

\section{DEVELOPMENT OF THE TARGET ORIENTATION OF THE PERSONALITY OF ADOLESCENT TOURISTS}

The article is devoted to the problem of personality target orientation, as one of the central component of the personality-motivational development of the teenager, in the context of sports and tourism activity.

The research is based on the assumption that accelerating the development of the target orientation of the individual in adolescents is possible by activating its components in the conditions of tourism activity. Present article provides the study model of the tennagers personality targeting.

The article presents the results of the study of the development of the target orientation of the personality of teenagers-tourists, supported by qualitative and quantitative research methods, in particular, the content structure of adolescent personality orientation and a number of key factors influencing orientation in these areas were analyzed. The research is based on the assumption that accelerating the development of the target orientation of the individual in adolescents is possible by activating its components in the conditions of tourism activity. It is statistically determined that the leading target areas of adolescent tourists are the individualistic and self-activity areas of interest; Friendly, family, and educational focuses are moderate, while the social and intimate target areas are the least prioritized.

In addition, the study of the personal position showed that among adolescents prevails self-centered position, the second largest is the rational position, the least common - the altruistic position.

It is found, that interaction in a group during competitions and trips promotes the development of teamwork and a comfortable microclimate that affects the emotional sphere of adolescents. The use of cards of the indicative basis of action at the training is cognitive activity, the growth of motivation to study, as well as the development of rational and altruistic positions of the target orientation of the personality of adolescents, thus contributing to the personnel development and subjective well-being. Situation of the test, that create personal challenge to teenager, during training and competitions, complex route sections and adverse weather conditions in the campaign cause adaptive correction of the condominium component. The system of job vacancies, tourist regulations and values contribute to the development of the value component of the target orientation of adolescents.

Keywords: psychological peculiarities of development, target orientation of the personality, personality of the teenager, tourist activity, professional sport.

Виталий Онищенко, студ.

Киевский национальный университет имени Тараса Шевченко, Киев, Украина

\section{РАЗВИТИЕ ЦЕЛЕВОЙ НАПРАВЛЕННОСТИ ЛИЧНОСТИ ПОДРОСТКОВ-ТУРИСТОВ}

Приведены результаты изучения развития целевой направленности личности подростков-туристов. Исследование основывалось на предположении о том, что ускорение развития целевой направленности личности у подростков возможно путем активизации ее составляющих в условиях туристической деятельности. Взаимодействие в группе во время соревнований и путешествий способствует развитию коллективизма и комфортного микроклимата, влияет на эмоциональную сферу подростков. Применение карточек ориентировочной основы действия на тренировках вызывает познавательную активность, рост мотивации к обучению, а также развитие рациональной и альтруистической позиций целевой направленности личности подростков. Ситуации испытания во время тренировок и соревнований, сложные участки маршрута и неблагоприятные погодные условия в походе вызывают коррекцию конативного компонента. Система сменных должностей, туристические правила и ценности способствуют развитию ценностного компонента целевой направленности подростков.

Ключевые слова: психологические особенности развития, целевая направленность личности, личность подростка, туристическая деятельность, профессиональный спорт 